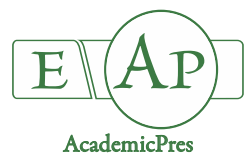

Available online: www.notulaebotanicae.ro

\title{
Outcrossing Rates and Gene Flow in Natural Population of the Endangered Endemic Aquatic Lycophyte Isoetes yunguiensis as Revealed by ISSR Markers
}

\author{
Mengxue $\mathrm{MA}^{\text {la }}$, Xiang DONG ${ }^{\mathrm{lb}}, \mathrm{Kuo} \mathrm{LIAO}^{2}$, Fei HAO ${ }^{3}$, Rui QIN ${ }^{1 *}$, \\ Hong LIU ${ }^{1 * *}$ \\ ${ }^{1}$ South-Central University for Nationalities, Key Laboratory for Protection and Application of Special Plant Germplasm in Wuling \\ Area of China, Wuhan 430074, HubeiProvince,China; mmengxue93@163.com; directx0831@163.com; \\ qin_rui@hotmail.com (*corresponding author);15102751466.com@163.com ( ${ }^{* *}$ corresponding author) \\ ${ }^{2}$ Wuhan Botanical Garden, Chinese Academy of Sciences, Key Laboratory of Aquatic Botany and Watershed Ecology, Wuhan 430074, \\ China;liaokuo@wbgcas.cn \\ ${ }^{3}$ Northwestern Polytechnical University, College of Life Science, Xian 710129, China; feib1942@mail.nwpu.edu.cn \\ ${ }^{a, b}$ These authors contributed equally to this work
}

\begin{abstract}
In this study, mating system, genetic diversity, and genetic structure of the endangered endemic aquatic Isoetes yunguiensis in China was investigated using ISSR markers. The results of ISSR analyses showed that the estimate of multilocus outcrossing rate $\left(t_{\mathrm{m}}\right)$ was high at species level $\left(t_{\mathrm{m}}=0.955\right)$, indicating that diploid I. yunguiensis is a predominant outcrossing species. Nine selected ISSR primers used in the study amplified 66 reproducible bands, 41 of which were polymorphic among 37 individuals. High level of genetic diversity was detected at the species level (PPB $=62.12 \%)$, whereas, relatively low genetic diversity existed within populations $(\mathrm{PPB}=39.39 \%)$. Analysis of molecular variance (AMOVA) revealed that $31.99 \%$ of the genetic variation was attributable to differences between populations and the rest $(68.01 \%)$ to variability within populationsof I. yunguiensis. Value of $\mathrm{F}_{\mathrm{st}}(0.320)$ indicated that genetic differentiation between populations also was significant. These results showed that I. yunguiensis predominantly favors crossing, and has a high level of genetic diversity and highly significant genetic variation between and within populations. Gene flow $(\mathrm{Nm})$ among populations is equal to 1.177. High outcrossing rates may be responsible for the high levels of genetic diversity observed in the I. yunguiensis population. To maintain the current level of genetic diversity for this species, we recommend increasing in situ conservation sites.
\end{abstract}

Keywords: endangered; genetic structure; ISSR; Isoetes yunguiensis; outcrossing rate

\section{Introduction}

Plant breeding systems determine gene flow, the genetic structure of populations, and the evolutionary potential of a species (Korpelainen, 1995). An accurate characterization of mating system is important for the conservation of the evolutionary potential of natural populations because it allows the outlining of strategies that optimize the sampling of genetic variability and the adoption of genetic-statistical models appropriate for the estimation of genetic parameters (Cánovas et al., 2015).

Isoetes L., the single remaining member of the family Isoetaceae, is a cosmopolitan genus of heterosporous lycopods comprising 200 or more species, and occupies a very important position in the evolutionary history of the pteridophytes (Hoot et al., 2001). Five species of Isoetes including I. hypsophila, I. yunguiensis, I. taiwanensis, I. orientalis and I. sinensis occur in China (Liu et al., 2005). Isoetes yunguiensis is an endangered and endemic aquatic fern in China, and is a basic diploid with a chromosome number $2 n=22$ (Wang et al., 2002). The species is a perennial distributed in ponds in riverside meadows and marshes at elevations of 1200-2200 $\mathrm{m}$ in the YunnanGuizhou Plateau in southwest China. In recent years, $I$. yunguiensis has declined rapidly in the number and size of populations due to the impact of human activities. Pang et al. (2003) reported that five I. yunguiensis populations such as Heilongtan, Songhuaba, Xiaoshao, Shuangshao and Xuandian populations in Kunming City, Yunnan Province 
340

based on specimen records may become extinct during the field investigation (Fig.1, Table 1). In field investigation, two populations, in Pingba County and Hongfenghu Lake, Guizhou Province, were found in China (Dong et al., 2018a). The species is now considered to be rare and threatened or endangered and is listed among first category of the Key Protected Wild Plants in China (Yu, 1999). Most of the previous studies of I. yunguiensis have mainly focus on its morphology, taxonomy, cytology, ecology and reproductive development (Wang et al., 2002; Pang et al., 2003; Chen et al., 2007; Li et al., 2015). Using RAPD markers, Chen et al. (2005a) reported high level of genetic diversity (Percentage of polymorphic bands, PPB = 62.1\%) from a remaining $I$. yunguiensis population in Pingba County, Guizhou Province, China. However, little is known about mating system, and population genetic structure of I. yunguiensis.

Mating systems of plants are commonly characterized by outcrossing rates. These estimates can be generated by examining allelic variation over many loci in progeny arrays from plants allowed to pollinate naturally, using a maximum-likelihood model to exclude progeny resulting from self-fertilization (Ritland and Jain, 1981). Outcrossing rates in plant populations have often performed using codominant markers such as SSR, allozyme (Chen et al., 2009; Suwarni et al., 2018). However, in the absence of sufficient allozyme polymorphism, several dominant markers such as RAPD (Gaiotto et al., 1997; Dong et al., 2006), ISSR (Han et al., 2009; Fernando et al., 2015; Saki et al., 2016), and AFLP (Gaiotto et al., 1997; Pometti et al., 2013., Zhao et al., 2014; Dong et al., 2018a; 2018b) have recently been used to estimate outcrossing rates in plant species.
Due to their dominant behaviour, these markers provide less information per locus than co-dominant markers. This is particularly relevant for applications that require genotype discrimination, as in the case of outcrossing-rate estimation. Through simulation studies, Ritland and Jain (1981) demonstrated, however, that this limitation could be readily overcome by multilocus estimation using a large number of dominant markers with intermediate gene frequencies.

In recent years, inter-simple sequence repeat (ISSR) have also been utilized as a tool in the study of conservation genetics and outcrossing rates (Han et al., 2009; Saki et al., 2016). ISSR is a technique that uses repeat-anchored primers to amplify DNA sequences between two-inverted SSR (Zietkiewicz et al., 1994). The technique does not require prior knowledge of the DNA sequence for primer design, and has advantages similar to those of RAPDs (Esselman et al., 1999). Furthermore, they are highly reproducible due to their primer length and to the high stringency achieved by the annealing temperature. Additionally, given the abundance of microsatellites sequences it is possible to analyze a large number of loci, giving high possibilities of finding polymorphisms, even in highly related genotypes (Carrasco et al., 2009). ISSR markers have been found to provide a much larger number of polymorphic fragments per primer than does RAPD and allozyme (Zietkiewicz et al., 1994; Han et al., 2009; Cheng et al., 2018). The objectives of our research was to use ISSR markers to evaluate outcrossing rates, and population genetic structure in natural populations of I. yunguiensis in China with the aim of providing baseline genetic information pertinent to the conservation and restoration of this endangered fern species.

Table 1. Geographic distribution, location, habitat, and sample size of Isoetes yunguiensis populations studied

\begin{tabular}{|c|c|c|c|c|c|c|c|c|c|}
\hline $\begin{array}{l}\text { Population } \\
\text { code }\end{array}$ & $\begin{array}{c}\text { Extant/ extinct } \\
\text { population }\end{array}$ & Locality & $\begin{array}{c}\text { Latitude/Longitude } \\
(\mathrm{N} / \mathrm{E})\end{array}$ & $\begin{array}{l}\text { Altitude } \\
(\mathrm{m})\end{array}$ & Habitats & $\begin{array}{l}\text { Population } \\
\text { size }\end{array}$ & $\begin{array}{l}\text { Population } \\
\text { area }\left(\mathrm{m}^{2}\right)\end{array}$ & $\begin{array}{c}\text { Sample } \\
\text { size }\end{array}$ & $\begin{array}{l}\text { Vouchers/ } \\
\text { References }\end{array}$ \\
\hline PB & Extant & $\begin{array}{l}\text { Pingba, } \\
\text { Guizhou }\end{array}$ & $26^{\circ} 25^{\prime} / 106^{\circ} 17^{\prime}$ & 1365 & Valley swamp & $40-50$ & $50-60$ & 19 & $\begin{array}{c}\text { HCAS } \\
75043 / \text { the } \\
\text { present study }\end{array}$ \\
\hline $\mathrm{QHH}$ & Extant & $\begin{array}{c}\text { Hongfenghu, } \\
\text { Guizhou }\end{array}$ & $26^{\circ} 29^{\prime} / 106^{\circ} 24^{\prime}$ & 1247 & Valley swamp & $40-45$ & $45-50$ & 18 & $\begin{array}{c}\text { The present } \\
\text { study }\end{array}$ \\
\hline KM1 & Extinct & $\begin{array}{l}\text { Heilongtan, } \\
\text { Kunming } \\
\text { City,Yunnan }\end{array}$ & $25^{\circ} 02^{\prime} / 102^{\circ} 42^{\prime}$ & 2000 & Pond & & & & $\begin{array}{c}\text { KUN } \\
0002883 / \text { Pang } \\
\text { et al., } 2003\end{array}$ \\
\hline KM2 & Extinct & $\begin{array}{l}\text { Songhuaba, } \\
\text { Kunming } \\
\text { City, Yunnan }\end{array}$ & $25^{\circ} 02^{\prime} / 102^{\circ} 42^{\prime}$ & 2000 & Reservoir & & & & $\begin{array}{c}\text { KUN } \\
\text { 0002885/ Pang } \\
\text { et al., } 2003\end{array}$ \\
\hline KM3 & Extinct & $\begin{array}{c}\text { Xiaoshao, } \\
\text { Kunming } \\
\text { City, Yunnan }\end{array}$ & $25^{\circ} 02^{\prime} / 102^{\circ} 42^{\prime}$ & 2000 & $\begin{array}{l}\text { Rice-field } \\
\text { stream }\end{array}$ & & & & $\begin{array}{c}\text { KUN } \\
\text { 0002888/ Pang } \\
\text { et al., } 2003\end{array}$ \\
\hline KM4 & Extinct & $\begin{array}{l}\text { Shuangshao, } \\
\text { Kunming } \\
\text { City, Yunnan }\end{array}$ & $25^{\circ} 02^{\prime} / 102^{\circ} 42^{\prime}$ & 2160 & $\begin{array}{l}\text { Rice-field } \\
\text { stream }\end{array}$ & & & & $\begin{array}{c}\text { KUN } \\
\text { 0002886/ Pang } \\
\text { et al., } 2003\end{array}$ \\
\hline XD1 & Extinct & $\begin{array}{c}\text { Xuandian, } \\
\text { Kunming } \\
\text { City, Yunnan }\end{array}$ & $25^{\circ} 56^{\prime} / 103^{\circ} 25^{\prime}$ & 2080 & $\begin{array}{l}\text { Rice-field } \\
\text { stream }\end{array}$ & & & & $\begin{array}{c}\text { KUN 65680/ } \\
\text { Pang et al., } \\
2003\end{array}$ \\
\hline
\end{tabular}




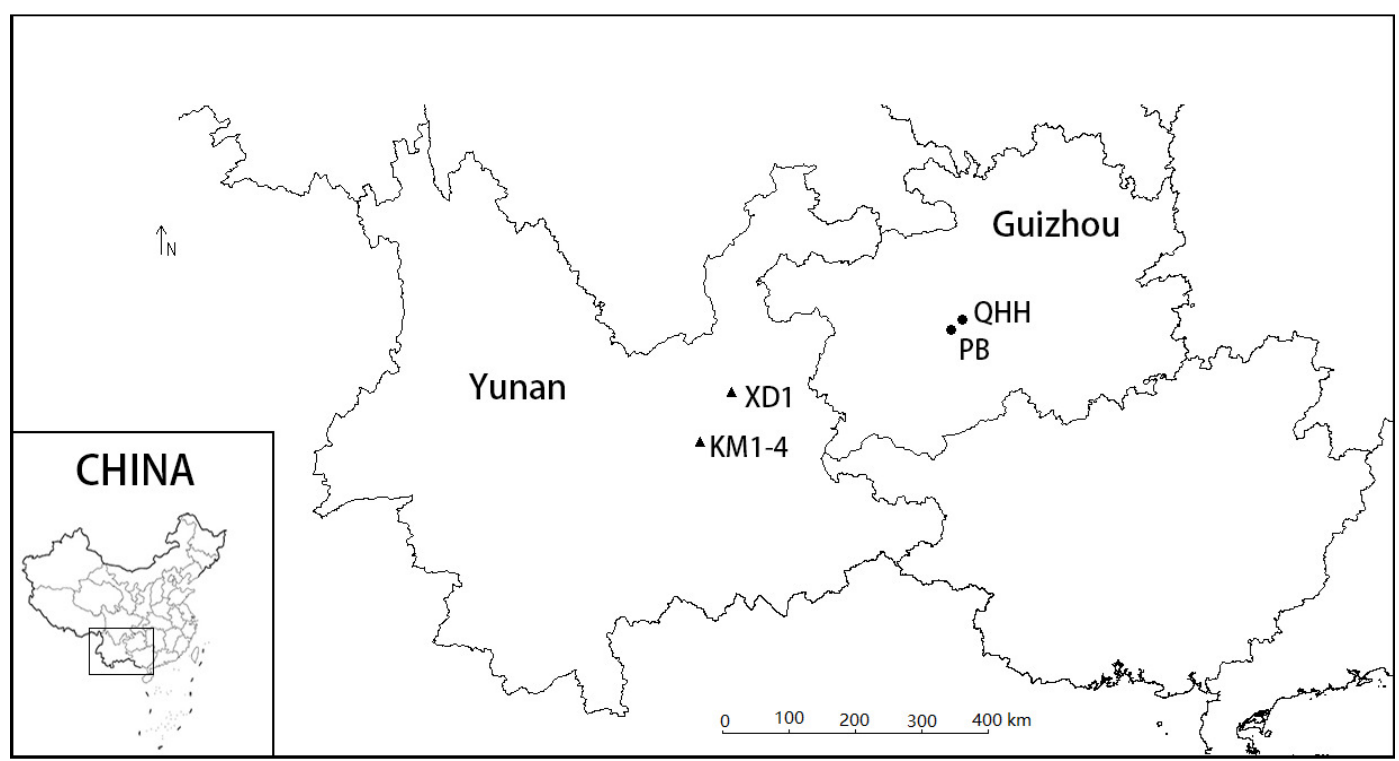

Fig. 1. Distribution map of Isoetes yunguiensis populations sampled in the present study. $\bullet$ Sites of extant populations. $\boldsymbol{\Delta}$ Sites of extinct populations (see Pang et al., 2003). Codes correspond to populations in Table 1

\section{Materials and Methods}

\section{Plant materials and total DNA extraction}

From 2003 to 2015, the historic geographic distributions of $I$. yunguiensis were investigated in China based on specimen records and observations made. The two extant populations (designated as $\mathrm{PB}, \mathrm{QHH}$ ) be found and located in Guizhou Province in China during the field surveys (Fig. 1), and were small, containing fewer than 50 individuals (Table 1). At each sampling site, latitude, longitude, and elevation were measured by Global Positioning System (GPS). The habitat characteristics of $I$. yunguiensis populations were studied by collecting (Table 1). The population characteristics of the species including population numbers and population area, population sizes (numbers of individuals) were investigated (Table 1). Because of the two populations are small populations and in order to minimize effect on these populations, each population has been collected only 18-19 samples. Individuals in each study population were sampled at a minimum distance of $1 \mathrm{~m}$ from one another. A total of 37 individuals from the two remaining populations of $I$. yunguiensi in this study were collected. Approximately 5-10 $\mathrm{g}$ of young leaves were harvested from each plant and immediately dried in a sealed ziplock plastic bag containing about $50 \mathrm{~g}$ of silica gel.
Total DNA was extracted from 0.3 to $0.5 \mathrm{~g}$ of silicadried leaf tissue following the procedure described by Doyle and Doyle (1987). The DNA concentration of each sample was determined with an Eppendorf BioPhotometer plus (Eppendorf AG, Hamburg, Germany).

\section{ISSR PCR amplification}

A total of eighty primers from SBS Genetech Co. Ltd. (Shanghai, China) were tested for PCR. Those that produced reproducible, clear, polymorphic electrophoretic bands were selected. PCR reactions were performed in a PTC $-100^{\mathrm{TM}}$ thermocycler (MJ Research, Inc.) using the following temperature cycle profile: an initial melting step at $94^{\circ} \mathrm{C}$ for $5 \mathrm{~min}$, followed by 35 cycles $94^{\circ} \mathrm{C}$ for $30 \mathrm{~s}, 55^{\circ} \mathrm{C}$ for $45 \mathrm{~s}, 72^{\circ} \mathrm{C}$ for $1.5 \mathrm{~min}$, and a finally $7 \mathrm{~min}$ at $72{ }^{\circ} \mathrm{C}$ for final extension. Reactions were carried out in a volume of 25 $\mu \mathrm{l}$, containing $0.25 \mathrm{mM}$ of each dNTP, $25 \mathrm{mM} \mathrm{MgCl}_{2}, 1.5$ $\mathrm{mM}$ primer, $2.5 \mathrm{U}$ Taq polymerase and $4 \mu \mathrm{l}(10 \mathrm{ng})$ of DNA template. PCR products were electrophoresed on $1.5 \%$ agarose gels stained with ethidium bromide, visualized under ultraviolet light, and photographed. Sizes of amplification products were estimated using a DL $2000 \mathrm{bp}$ DNA ladder. Eighty ISSR primers were screened on four randomly selected individuals. Nine primers that could produce clear and reproducible fragments were chose for further analysis (Table 2).

Table 2. Primers used in the ISSR study

\begin{tabular}{|c|c|}
\hline Primer & Sequence $\left(5^{\prime}-3^{\prime}\right)$ \\
\hline SBS 816 & $(\mathrm{CA})_{8} \mathrm{~T}$ \\
\hline SBS 834 & $(\mathrm{AG})_{8}(\mathrm{C} / \mathrm{G}) \mathrm{T}$ \\
\hline SBS 836 & $(\mathrm{AG})_{8}(\mathrm{C} / \mathrm{G}) \mathrm{A}$ \\
\hline SBS 840 & $(\mathrm{GA})_{8}(\mathrm{C} / \mathrm{G}) \mathrm{T}$ \\
\hline SBS 841 & $(\mathrm{GA})_{8}(\mathrm{C} / \mathrm{G}) \mathrm{C}$ \\
\hline SBS 842 & $(\mathrm{GA})_{8}(\mathrm{C} / \mathrm{G}) \mathrm{G}$ \\
\hline SBS 845 & $(\mathrm{CT})_{8}(\mathrm{~A} / \mathrm{T}) \mathrm{G}$ \\
\hline SBS 858 & $(\mathrm{TG})_{8}(\mathrm{~A} / \mathrm{T}) \mathrm{G}$ \\
\hline SBS 880 & $(\text { GGAGA })_{3}$ \\
\hline
\end{tabular}


342

\section{Data analysis}

Matingsystem

According to the molecular weight (bp), all individuals were scored for the presence (1) or absence (0) of the amplified ISSR fragments, and the data matrix of the ISSR phenotypes was constructed for further analysis. The programme MLTR 3.4 (Ritland, 2009) is based on the multilocus mixed-mating model and the estimation procedure of Ritland and Jain (1981) which assumes that progeny are derived from either random mating (outcrossing) or self-fertilization. Using the software MLTR 3.4 (Ritland, 2009), the following mating system parameters were calculated: the estimate of multilocus outcrossing rate $\left(t_{\mathrm{m}}\right.$, a maximum likelhood estimate of $\left.t_{\mathrm{m}}=1.2\right)$ and single locus outcrossing rate $\left(t_{\mathrm{s}}\right)$, correlation of outcrossed paternity (rp), correlation of $t_{\mathrm{m}}$ among progeny arrays ( $\mathrm{rt}$ ), and fixation index of maternal parents $(F)$. The biparental inbreeding rate was also estimated following Ritland (1990) as $t_{\mathrm{m}}-t_{\mathrm{s} .}$. The standard errors for these parameters were calculated from 1000 bootstraps with resampling of individuals within families. Standard error was used to determine whether mating parameters were significantly lower than one or greater than zero.

\section{Genetic diversity and gene flow}

Genetic diversity was measured by the percentage of polymorphic bands ( $\mathrm{PPB}$ ), which was calculated by dividing the number of polymorphic bands at population, and species levels by the total number of bands surveyed. PPB, the Shannon index of diversity $(I)$, and the gene diversity index $(H)$ were calculated to evaluate genetic diversity. All calculations were estimated using POPGENE program Version 1.32 (Yeh et al., 2000).

\section{Genetic structure}

Genetic variation within and among populations was further partitioned by analysis of molecular variance (AMOVA) using ARLEQUIN 3.5.2 (Excoffier and Lischer, 2015). The AMOVA-based estimate of population genetic differentiation between two populations (Fixation index, F FT) was calculated. The Nei and $\mathrm{Li}$ (1979) coefficient for measuring pairwise band similarities between individuals was calculated using NTSYSpc ver. 2.02 (Rohlf, 1998). The dendrogram (UPGMA) of all individuals was computed using the unweighted pair-group method with an arithmetic average using NTSYSpc ver. 2.02 (Rohlf, 1998). Significance tests were made after 1000 permutations.

\section{Results and Discussion}

\section{Mating system analysis}

The estimate of multilocus outcrossing rates $\left(t_{\mathrm{m}}\right)$ and single locus outcrossing rates $\left(t_{\mathrm{s}}\right)$ were higher in species level $\left(t_{\mathrm{m}}=0.955, t_{\mathrm{s}}=0.953\right.$, respectively) and all populations (PB population: $t_{\mathrm{m}}=1.200, t_{\mathrm{s}}=1.164 ;$ QHH population: $t_{\mathrm{m}}=$ $1.200, t_{\mathrm{s}}=1.160$, respectively), indicating that $I$. yunguiensis studied is mostly outcrosser (Table 3 ). The difference between $t_{\mathrm{m}}$ and $t_{\mathrm{s}}(0.002)$ in species level was insignificant, suggesting that biparental inbreeding was negligible (Ritland, 1990), indicating that there is a low tendency for mating between relatives (Table 3). The correlation of $t_{\mathrm{m}}$ within progeny arrays $(\mathrm{rt})$ was low in all populations $(\mathrm{PB}$ population: $-0.315 \pm 0.185$; QHH population: $-0.999 \pm$ 0.164 , respectively), suggesting no differences in outcrossing rates among mother plants (Table 3). The low $F$-value $(0.082)$ of the maternal parents suggested that there were an excess of heterozygotes and less inbreeding in the progeny population analyzed (Table 3).

The equivalent to crossing in higher plants involves crosses between gametophytes produced by spores from different sporophytes, termed intergametophytic crossing or xenogamy (Hickok et al., 1995). The reproductive structure and characteristics of ferns not only have a stable systematic significance, but also determine the reproductive mode and reproductive function (Wu and Qin, 1991). I. yunguiensis is a heterosporous fern, which can produce two kinds of different spore namely microspores and megaspores, and produce male gametophyte and female gametophyte respectively (Li et al., 2015). The reproductive structure and characteristics of $I$. yunguiensis determine that sexual reproduction model of I. yunguiensis is outcrossing by combining of sperm and egg cells from different sporophytes and gametophytes.

\section{Genetic diversity and genetic structure}

The nine selected primers generated a total of 66 bands (an average of 7.4 bands/primer). A total of 41 bands were polymorphic among 37 individuals (Table 4). The percentage of polymorphic bands (PPB) for this species was $62.12 \%$, indicating high levels of genetic diversity at the species level. Nei's unbiased genetic identity $(H)$ and the Shannon' information index (I) also showed a similar pattern of the genetic differentiation at the species level $(H$ $=0.239 ; I=0.354$, respectively). Within populations, ISSR diversity $(\mathrm{PPB}=39.39 \%)$ was lower than at the species level (Table 4). The results of ISSR diversity analysis among populations and within populations of I. yunguiensis in China obtained in the study were similar to those reported in previous studies on other fern species. For example, Chen et al. (2006) revealed 51.02\% ISSR genetic diversity between populations and within populations (an average of PPB: ISSR, 16.32\%) of the endangered aquatic fern $I$. sinensis in China based on ISSR data. Chen et al. (2005b) using RAPD and ISSR also reported high genetic diversity at the species level of the endangered aquatic fern $I$. hypsophila in China (PPB: RAPD 50.0\%, ISSR 82\%, respectively) and low genetic diversity among populations with $\mathrm{PPB}$ values ranging from 7.69 to $25.96 \%$ (RAPD), from 8 to 35\% (ISSR), respectively. Using AFLP, Kang et al. (2005) revealed high genetic diversity (61.2\%) among population levels of $I$. sinensis. Results of ISSR diversity analysis of I. yunguiensis in China obtained in this study were higher than those obtained for other rare and endangered fern species. For instance, Chen et al. (2010a) using AFLP data revealed low genetic diversity among population levels of I. hypsophila, an endangered alpine quillwort fern in China (PPB: 48.5\%). Using AFLP, Kim et al. (2009) reported low genetic diversity (PPB) of six endangered Isoetes species from East Asia including $I$. taiwanensis (33.1-38.3\%), I. asiatica (49.0\%), I. jejuensis 
(9.3-29.3\%), I. hallasanensis (22.3\%), I. coreana (1.6-20.6\%), and I.japonica (5.6-20.5\%). A low level of gene diversity was also found at the population level in C.pteridoides based on ISSR, RAPD and AFLP markers (PPB: RAPD 33.6\%, ISSR 44.8\%, AFLP 17.4\%, respectively) (Dong et al. 2007, 2010; Chen et al., 2010b).

Among several life-history traits, the breeding system is considered to be the most important to determine the level of genetic variability and its distribution in populations of plant species (Kim et al., 2009). In general, outcrossing species usually have higher levels of genetic diversity and lower differentiation between populations than selfing and clonal plants (Holsinger, 2000). Results of Peredo et al. (2013) also confirm the importance of reproduction system in the genetic diversity present in populations of some fern species such as Blechnum spicant and Dryopteris affinis ssp. affini. The results indicated that $I$. yunguiensis predominantly favour gametophytic crossing $\left(t_{m}=0.955\right)$ (Table 3). Therefore, it is probable that high outcrossing rate of this species may have played an important role in maintaining the generally high level of interpopulation genetic diversity in the endangered I.yunguiensis.

AMOVA of ISSR data revealed that $31.99 \%$ of the total genetic variation was attributable to among populations and $68.01 \%$ partitioned among individuals within populations of I. yunguiensis, indicating variation existed mainly within populations rather than among populations (Table 5). Generally, values of $F_{S T}$ above 0.25 indicate very great genetic differentiation (Wright, 1978). In this study, the AMOVA-based estimate of population differentiation between two I. yunguiensis populations was $\mathrm{F}_{\mathrm{ST}}$ (Fixation index $)=0.320$, indicating genetic differentiation between populations $\left(\mathrm{F}_{\mathrm{ST}}\right)$ was significant. Thus, the results indicated that there is almost always more variation explained among individuals within populations in all AMOVA analyses and this is not preclude there being strong and significant variation among/between populations. According to the Nei-Li genetic similarity of 0.80 , a UPGMA cluster analysis of 37 individuals indicated that samples form two groups, one formed by the population $\mathrm{QHH}$ and other by the population $\mathrm{PB}$, what the UPGMA tree has is only four QHH samples in the PB group (Fig. 2). The result of UPGMA cluster analysis further indicated that there was salient genetic differentiation between the two extant populations in China.

In the study, ISSR data showed that interpopulational gene flow (Nm) of I. yunguiensis was 1.177.
The observed level of gene flow was lower than that in the endangered aquatic Isoetes in China, such as I. sinensis (Allozyme analysis: $\mathrm{Nm}=4.51$; Chen et al., 2004). High gene flow in some diploid homosporous ferns, including Polystichum munitum $(\mathrm{Nm}=24.00), P$. acrostichoides $(\mathrm{Nm}$ $=12.69), P$. dudleyi $(\mathrm{Nm}=10.78)$, and $P$. imbricans $(\mathrm{Nm}=$ 2.2), was also observed (Soltis and Soltis, 1990). The results show that gene flow between populations of I. yunguiensis is quite restricted. In plants, gene flow is occasioned by movement of pollen, seeds, spores, and propagules (Orive and Asmussen, 2000). Dispersal of Isoetes spores is often accomplished via floating leaves (Small and Hickey, 1997). A survey indicates that young plants of Isoetes in China are swept away from the headstream on mountains to lower reaches of a river by floods (Liu et al., 2004). Habitat fragmentation and isolation of population may limit gene flow, the result are increased inbreeding and genetic drift, and leading to decreasing genetic diversity, resulting in population differentiation (Primack, 1993; Li and Jin, 2008). Field survey found that the distance of two $I$. yunguiensis populations is about $15 \mathrm{~km}$, and have been isolated (Fig. 1). The isolation of population resulted in the limitation of spore dispersal, which reduced gene flow. Chen et al. (2005b, 2010a) also suggested that habitat isolation could have greatly limited gene flow between $I$. hypsophila populations from different geographical regions, hence increasing the interpopulation differentiation of $I$. hypsophila. Yang et al. (2011) revealed a high level of gene flow via spore dispersal $(\mathrm{Nm}=16.66)$ in neighbor ex-situ Isoetes subpopulations alone main water flow and low genetic differentiation among conservation subpopulations $\left(\mathrm{G}_{\mathrm{st}}=0.07\right)$. Furthermore, Li et al. (2015) reported that the swimming speed of I. yunguiensis sperm is $79 \mu \mathrm{m} / \mathrm{s}$ and its life time is only $11 \mathrm{~min}$, indicating long-distance movement of sperm among populations may be restricted. Therefore, spore dispersal and swimming sperm of I. yunguiensis is likely to be restricted between populations, and might have reduced gene flow. It is likely that the restricted gene flow between the populations in I. yunguiensis may have played an important role in determining the genetic differentiation of I. yunguiensis populations.

Because we are dealing with an endangered species and restricted population sizes at two sites, the sample sizes in the populations varied in the range 18-19; this may have led to bias in some statistical analyses of the data.

Table 3. Mating system parameter of Isoetes yunguiensis populations studied in China

\begin{tabular}{cccc}
\hline Parameter & $\mathrm{PB}$ & QHH & Species level \\
\hline$t_{\mathrm{m}}$ & $1.200(0.064)$ & $1.200(0.035)$ & $0.955(0.105)$ \\
$t_{\mathrm{s}}$ & $1.164(0.051)$ & $1.160(0.034)$ & $0.953(0.062)$ \\
$t_{\mathrm{m}-t_{\mathrm{s}}}$ & $0.036(0.045)$ & $0.040(0.033)$ & $0.002(0.057)$ \\
$\mathrm{rp}(\mathrm{m})$ & $-0.142(0.300)$ & $0.000(0.350)$ & $0.279(0.034)$ \\
$\mathrm{rp}(\mathrm{s})$ & $-0.250(0.176)$ & $-0.332(0.127)$ & $-0.047(0.108)$ \\
$\mathrm{rp}(\mathrm{s})-\mathrm{rp}(\mathrm{m})$ & $-0.108(0.317)$ & $-0.332(0.329)$ & $-0.076(0.078)$ \\
$\mathrm{rt}$ & $-0.315(0.185)$ & $-0.999(0.164)$ & $-0.999(0.000)$ \\
$\mathrm{F}$ & $-0.200(0.029)$ & $-0.200(0.019)$ & $0.082(0.141)$
\end{tabular}

$t_{\mathrm{m}}$, Multilocus outcrossing rate; $t_{\mathrm{s}}$, Single-locus outcrossing rate; $t_{\mathrm{m}}-t_{\mathrm{s}}$, Difference of outcrossing rate or biparental inbreeding; rp $(\mathrm{m})$, The multilocus correlation of paternity; $\mathrm{rp}(\mathrm{s})$, The single-locus correlation of paternity; $\mathrm{rp}(\mathrm{s})-\mathrm{rp}(\mathrm{m})$, Parents correlation; rt, Correlation of $\mathrm{t}$ (or $\mathrm{s}$ ) estimate; F, Inbreeding coefficient of the maternal parents; Numbers in parentheses are standard deviations (SD). 
344

Table 4. Genetic diversity of two Isoetes yunguiensis populations studied in China

\begin{tabular}{ccccccc}
\hline Population code & $\begin{array}{c}\text { Number of } \\
\text { polymorphic bands }\end{array}$ & PPB (\%) & Na & Ne & $H$ & $I$ \\
\hline PB & 26 & 39.39 & $1.394(0.492)$ & $1.300(0.405)$ & $0.165(0.216)$ & $0.237(0.308)$ \\
QHH & 26 & 39.39 & $1.394(0.492)$ & $1.311(0.407)$ & $0.171(0.218)$ & $0.246(0.311)$ \\
Species level & 41 & 62.12 & $1.621(0.488)$ & $1.410(0.372)$ & $0.239(0.200)$ & $0.354(0.289)$ \\
\hline
\end{tabular}

PPB, Percentage of polymorphic bands; Na, Observed number of alleles; Ne, Effective number of alleles; $H$, Nei's gene diversity index; $I$, Shannon's information index; Numbers in parentheses are standard deviations.

Table 5. Analysis of molecular variance (AMOVA) for ISSR data of 37 individuals from two populations of Isoetes yunguiensis

\begin{tabular}{ccccc}
\hline Source of variation & d.f. & SSD & Variance component & Percentage of variation $(\%)$ \\
\hline Among populations & 1 & 43.742 & 2.122 & 31.99 \\
Within population & 35 & 157.880 & 4.511 & 68.01 \\
Total level & 36 & 201.622 & 6.633 & $<0.001$ \\
\hline
\end{tabular}

d.f., degree of freedom; SSD, sum of squared deviation; *Statistical significance is based on 1000 permutations.

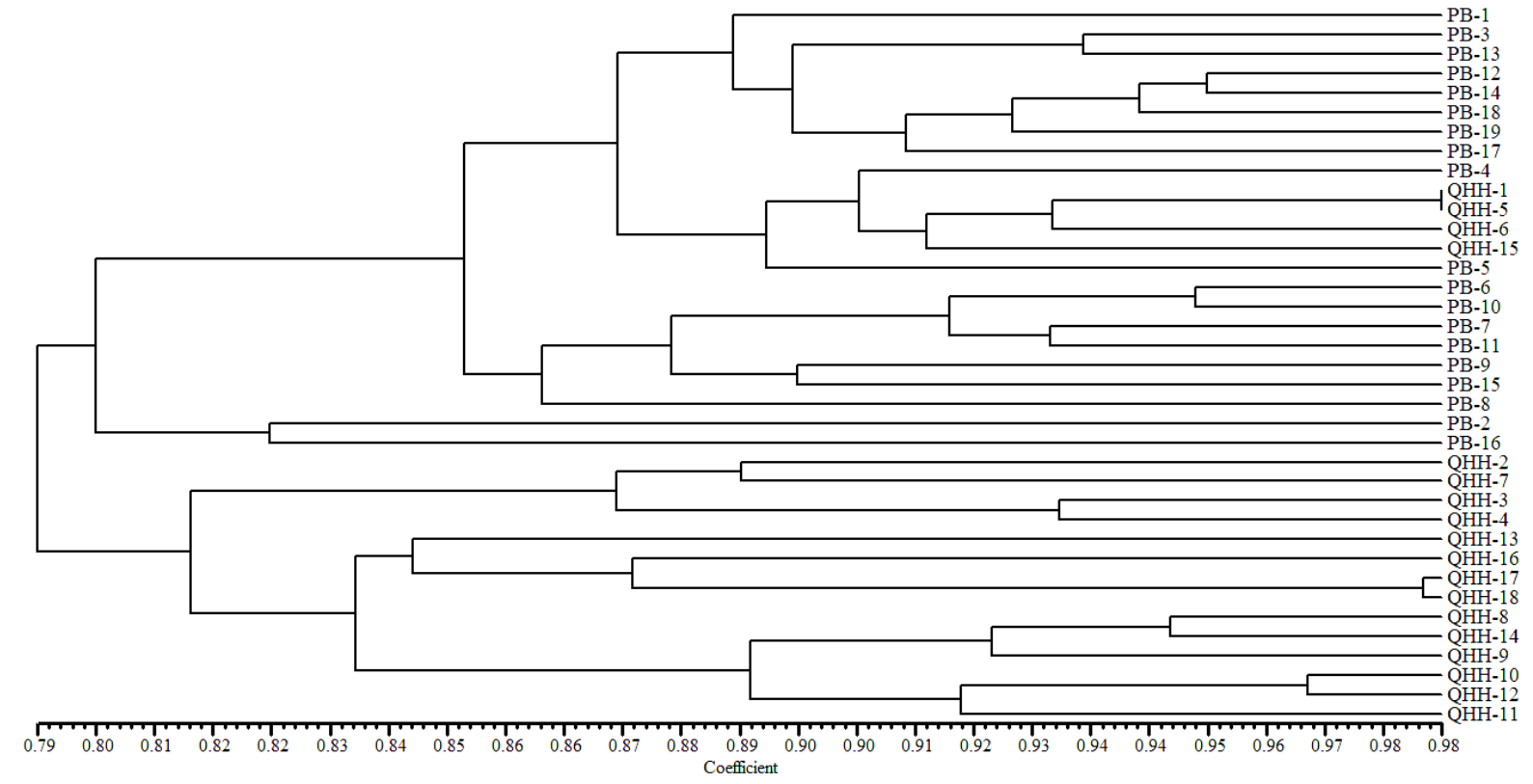

Fig. 2. UPGMA dendrogram of 37 individuals of Isoetes yunguiensis based on ISSR data. The first two or three letters represent the population code, and the number is the individual from each population

\section{Implications for conservation}

Habitat preservation is one of the most effective measures of conservation of species (Primack, 1993). The accelerated loss of habitat of I. yunguiensis in China puts the species at a risk of becoming extirpated (Pang et al., 2003; Chen et al., 2005a). The rapid reduction in numbers and sizes of I. yunguiensis populations in China is probably associated with human actives, contributing to the deterioration and loss of primary habitats (Pang et al., 2003). It is therefore, an important conservation strategy to protect more of the habitats of the remaining I. yunguiensis populations. It is worthy of notice that $\mathrm{PB}$ population have been protected by establishment of nature reserves at their locations. The in situ conservation was supported by grants from World Wide Fund for Nature or World Wildlife Fund (WWF) in 2007. In addition to habitat preservation, a key aim of conservation is to maintain a species' existing level of genetic variation in order to maximize its chances for persistence in the face of changing environments. Maintenance of genetic diversity is a major focus in conservation biology because it is important for a species to maintain its evolutionary potential to cope with an everchanging environment (Chen et al., 2010a). Choice of in situ sites and the appropriate ex situ conservation strategies require adequate genetical data on the species to be conserved. The genetic information obtained in this study should help to provide a clear framework for developing a conservation program for the threatened species $I$. yunguiensis. The low level of genetic diversity within populations of I. yunguiensis indicated that efforts should try to preserve every existing population. However, both the extant $\mathrm{PB}$ population and $\mathrm{QHH}$ population was small population, with the continuing decrease of numbers and sizes of populations, the genetic diversity will gradually be lost. Therefore, we suggest that the materials from the extant population should be used for re-establishment of the populations.

A good knowledge of mating system of I. yunguiensis will provide critical base-line information for developing sustainable management strategies. Based on the results of 
mating system of the species, we suggest that its conservation and restoration genetics should particularly also focus on the maintenance of historically significant processes such as high levels of outbreeding, and mixing more individuals from different populations in ex situ conservation, and minimizing inbreeding and enhancing gene flow in order to preserve the greatest extent of genetic resources within the species.

\section{Conclusions}

Our results revealed that I. yunguiensis predominantly favors crossing, and has a high level of genetic diversity and highly significant genetic variation between and within populations. Facts that may affect the genetic structure of the species include the high outcrossing rates, gene flow, spore dispersal and swimming sperms. The extant $I$. yunguiensis populations in China should be a priority for in situ conservation.

\section{Acknowledgements}

The work was supported by the National Natural Science Foundation of China (grant number 31170341, 31200170). The study was also financially supported by the National Species Fund on Basic Research of Science and Technology of China (grant number 2014FY110100) and the Construction Plan of Hubei Province Science and Technology basic conditions platform (2017BEC014).

\section{References}

Cánovas JL, Jiménez JF, Mota JF, Gómez PS (2015). Genetic diversity of Viola cazorlensis Gand, an endemic species of Mediterranean dolomitic habitats: implications for conservation. Systematics and Biodiversity 13:571-580.

Carrasco B, Ávila P, Perez-Diaz J, Muñoz P, Garcia R, Lavandero B, ZuritaSilva A, Retamales JB, Caligari PDS (2009). Genetic structure of highland papayas (Vasconcellea pubescens (Lenné et C. Koch) Badillo) cultivated along a geographic gradient in Chile as revealed by Inter Simple Sequence Repeats (ISSR). Genetic Resources and Crop Evolution 56:331-337.

Chen JM, Gituru WR, Liu X, Wang QF (2007). Genetic diversity in Isoetes yunguiensis, a rare and endangered endemic fern in China. Frontiers of Biology in China 2:46-49.

Chen YY, Ye QG, Li ZZ (2004). Genetic structure of Xiuning population of Isoetes sinensis, a critically endangered species in China. Chinese Biodiversity 12:564571.

Chen JM, Liu X, Wang QF. (2005a). Genetic diversity in Isoetes yunguiensis, a rare and endangered endemic fern in china. Wuhan University Journal(Natural ScienceEdition) 51:767-770.

Chen JM, Liu X, Wang JY, Gituru WR, Wang QF (2005b). Genetic variation within the endangered quillwort Isoëtes hypsophila (Isoëtaceae) in China as evidenced by ISSR analysis. Aquatic Botany 82:89-98.

Chen JM, Wang QF (2006). Genetic diversity in the rare and endangered fern Isoetes orientalis. Journal of Wuhan Botanical Research 24:569-573.
Chen GQ, Huang HW, Crawford DJ, Pan BR, Ge XJ (2009). Mating system and genetic diversity of a rare desert legume Ammopiptanthus nanus (Leguminosae). Journal of Systematic and Evolution 47:57-66.

Chen YY, Liao Li, Li W, Li ZZ (2010a). Genetic diversity and population structure of the endangered alpine quillwort Isoetes hypsophila Hand.Mazz. revealed by AFLP markers. Plant Systematics and Evolution 290:127-139.

Chen YY, Han QX, Cheng Y, LiZZ, Li W (2010b). Genetic variation and clonal diversity of the endangered aquatic fern Ceratopteris pteridoides as revealed by AFLP analysis. Biochemical Systematics and Ecology 38:1129-1136.

ChengJY, Jiang DZ, Cheng H, Zhou XH, Fang YY, Zhang XH, Xiao X, Deng XZ, Li LL (2018). Determination of Camellia oleifera Abel. germplasm resources of genetic diversity in China using ISSR markers. Notulae Botanicae Horti Agrobotanici Cluj-Napoca 46:165-172.

Dong ZR, Chen JM, Wang QF (2006). RAPD analysis for mating system in Caldesia parnassifolia. Journal of Wuhan Botanical Research 24:167170.

Dong YH, Chen JM, Gituru WR, Wang QF (2007). Gene flow in populations of the endangered aquatic fern Ceratopteris pteridoides in China as revealed by ISSR. Aquatic Botany 87:69-74.

Dong YH, Gituru WR, Wang QF (2010). Genetic variation and gene flow in the endangered aquatic fern Ceratopteris pteridoides in China, and conservation implication. Annales Botanici Fennici 47:3444.

Dong X, Liao K, Hao F, Liu H,Qin R (2018a). Mating system and genetic variability of the endangered endemic aquatic lycophyte, Isoetes yunguiensis, in China determined using AFLP markers. American Fern Journal 108(2):47-61.

Dong X, Liu H, Gao W, Qin R, Gichira AW, Wang M, Liao K (2018b). Estimation of mating system in the endangered aquatic fern Ceratopteris pteridoides in China based on AFLP molecular marker and selfing test: implications for conservation. Notulae Botanicae Horti Agrobotanici Cluj-Napoca 46:688-699.

Doyle JJ, Doyle JL (1987). A rapid DNA isolation method for small quantities of fresh tissues. Phytochemical Bulletin 19:11-15.

Esselman EJ, Li JQ, Crawford D, Winduss JL, Wolfe AD (1999). Clonal diversity in the rare Calamagrostis porteri ssp. insperata (Poaceae): comparative results for allozymes and random amplified polymorphic DNA (RAPD) and inter-simple sequence repeat (ISSR) markers. MolecularEcology 8:443451.

Excoffier L, Lischer H (2015). Arlequin ver. 3.5.2: An integrated software package for population genetics data analysis. Institute of Ecology and Evolution, University of Berne, Switzerland. http://cmpg.unibe.ch/software/arlequin3.

Fernando DD, Discenza JJ, Bouchard JR, Leopold DJ (2015). Genetic analysis of the threatened American hart's-tongue fern (Asplenium scolopendrium var.americanum [Fernald] Kartesz and Gandhi): Insights into its mating system and implications for conservation. Biochemical Systematics and Ecology 62:25-35.

Gaiotto FA, Bramucci M, Grattapaglia D (1997). Estimation of outcrossing rate in a breeding population of Eucalyptus urophylla with dominant RAPD and AFLP markers. Theoretical and Applied Genetics 95:842849. 
346

Han YC, Teng CZ, Wahiti GR, Zhou MQ, Hu ZL, Song YC (2009). Mating system and genetic diversity in natural populations of Nelumbo nucifera (Nelumbonaceae) detected by ISSR markers. Plant Systematics and Evolution 277:13-20.

Hickok LG, Warne TR, Fribourg RS (1995). The biology of the fern Ceratopteris and its use as a model system. International Journal of Plant Sciences 156:332-345.

Hoot SB, Taylor WC (2001). The utility of nuclear ITS, a LEAFY homolog intron, and chloroplast atpB-rbcL spacer region data in phylogenetic analyses and species delimitation in Isoetes. American Fern Journal 91:166-177.

Holsinger KE (2000). Reproductive systems and evolution in vascular plants. Proceedings of the National Academy of Sciences of the United States of America 97:7037-7042.

Kim C, Shin H, Choi HK (2009). Genetic diversity and population structure of diploid and polyploidy species of Isoetes in East Asia based on AFLP marker. International Journal of Plant Sciences 170: 496-504.

Korpelainen H (1995). Mating system and distribution of enzyme genetic variation in bracken (Pteridium aquilinum). Canadian Journal of Botany 73:1611-1617.

Kang M, Ye Q, Huang H (2005). Genetic consequence of restricted habitat and population decline in endangered Isoetes sinensis (Isoetaceae). Annals ofBotany 96(7):1265-1274.

LiJM,Jin ZX(2008). Genetic structure of endangered Emmenopterys henryi Oliv. Based on ISSR polymorphism and implications for its conservation. Genetica 133:227-234.

Li XD, Tan GJ, Li XX, Liu BD (2015). Comparative study about development of microgametopyte of two endangered endemic quillwort species in China. ActaBotanicaBoreali-Occidentalia Sinica 35:1142-1147.

Liu H, Wang QF, Taylor WC (2005). Isoetes orientalis (Isoetaceae), a new hexaploid quillwort from China. Novon 15:164167.

Liu X, Gituru WR, Wang QF (2004). Distribution of basic diploid and polyploid species of Isoetes in East Asia. Journal of Biogeography 31:1239-1250.

Nei M, Li WH (1979). Mathematical model for studying genetic variation in terms of restriction endonucleases. Proceedings of the National Academy of Sciences of the UnitedStates of America 76:5269-5273.

Orive ME, Asmussen MA (2000). The effect of pollen and seed migration on nuclear-dicytoplasmic systems. II. A new method for estimating plant gene flow from joint nuclear-cytoplasmic data. Genetics 155:833-854.

PangXA, Liu X, Liu H, Wu C, WangJY, YangSX, WangQF (2003). The geographic distribution and habitat of the Isoetes plants in China. Biodiversity Science 11:288-294.

Peredo EL, Méndez-Couz M, Revilla MA, Fernández H (2013). Mating system in Blechnum spicant and Dryopteris affinis ssp. affinis correlates with genetic variability. American Fern Journal 103:27-39.

Pometti CL, Bessega CF, Vilardi JC, Saidman BO (2013). Comparison of mating system parameters and genetic structure in three natural scenarios of Acacia visco (Leguminosae, Mimosoideae). Plant Systematics and Evolution 299:761-771.
Primack RB (1993). Essentials of conservation biology. Sinauer Associates, Inc, Sunderland, MA.

Ritland K, Jain S (1981). A model for the estimation of outcrossing rate and genefrequencies usingn independent loci. Heredity 47:35-52.

Ritland K (1990). A series of FORTRAN computer programs for estimating plant matingsystems. Journal of Heredity 81:235-237.

Ritland K (2009). Multilocus mating system program MLTR Version 3.4. University of British Columbia, Canada. http://genetics.forestry. ubc.ca/ritland/programs.html.

RohlfFJ (1998). NTSYSpc: Numerical taxonomy and multivariate analysis system, version 2.02. Exeter Software, Setauket, New York.

Saki S, Bagheri H, Deljou A, Zeinalabedini M (2016). Evaluation of genetic diversity amongst Descurainia sophia L. genotypes by inter-simple sequence repeat (ISSR) marker. Physiology and Molecular Biology of Plants 22:97-105.

Small R, Hickey RJ (1997). Levels and patterns of genetic variation in Isoetes karstenii with observations on I. palmeri. American Fern Journal 87:104115.

Soltis PS, Soltis DE (1990). Genetic variation within and among populations offerns. American Fern Journal 80:161-172.

SuwarniE, Omondi SF, Dancik BP, Khasa DP (2018). Estimation of pollen contamination and mating system in Pinus merkusii seedling seed orchard using allozyme markers. Journal of Tropical Forest Science 30:95-105.

Wang QF, Liu X, Taylor WC, He ZR (2002). Isoetes yunguiensis (Isoetaceae), a new basic diploid quillwort from China. Novon 12:587591.

Wright S (1978). Variability within and among natural populations. University ofChicago Press, Chicago.

WuZH, Qin RC (1991). Fern Families and Genera ofChina. Science Press, Beijing.

Yang H, Chen YY, Xu YX, Li ZZ (2011). Gene flow dynamics of ex-situ conservation populations in two endangered Isoetes species: genetic implications for reintroduction, conservation and management. Plant Science Journal 20:319-330.

Yeh FC, Yang R, Boyle TJ (2000). PopGene32: Microsoft Windows-based Freeware for Population Genetic Analysis (version 1.32). Molecular Biology and Biotechnology Centre, University of Alberta, Alberta, Canada.

Yu YF (1999). A milestone of wild plant conservation in China. Plants 5:311.

Zietkiewicz E, Rafalski A, Labuda D (1994). Genome fingerprinting by simple sequence repeat (SSR)-anchored polymerase chain reaction amplification. Genomics 20:176-183.

Zhao HB, Zhou LH, Liu HH, Bao ZY (2014). Genetic effects of different mating modes in Sinocalycanthus chinensis (Cheng et S.Y. Chang) Cheng et S.Y. Chang, an endangered species endemic to Zhejiang Province, China. Biochemical Systematics and Ecology 54:8-14. 